w rozwoju myśli pedagogicznej. Z kolei w sekcji III pt. „Oświata i szkolnictwo” dyskutowano głównie nad problemami organizacji i funkcjonowania szkolnictwa różnych szczebli, rolą towarzystw oświatowych w rozwoju szkolnictwa. Zaprezentowano także sylwetki wybitnych pedagogów i działaczy oświatowych.

Przedstawiony przez referentów materiał dał podstawy do owocnej dyskusji, w wyniku której wysunięto wiele postulatów badawczych, wskazujących na potrzebę zorganizowania kolejnej konferencji z serii „Galicja i jej dziedzictwo”.

Konferencji towarzyszył kiermasz wydawnictw książowych, podczas którego rozprowadzano m.in. wydawnictwa $z$ poprzednich sesji naukowych.

Madyslawa Szulakiewicz

\title{
„Nauczanie w Polsce średniowiecznej i wczesnonowożytnej” Mąchocice-Ameliówka kolo Kielc, 18-20 maja 1995 r.
}

W dniach od 18 do 20 maja 1995 odbyła się w Mąchocicach-Ameliówce koło Kielc konferencja naukowa poświęcona nauczaniu w Polsce w średniowieczu i w czasach nowożytnych. Sesję tą zorganizował Instytut Historii Wyższej Szkoły Pedagogicznej w Kielcach, a otwarcia obrad dokonal dyrektor Instytutu Historii WSP prof. Adam Massalski.

W pierwszym đniu konferencji (18.05) wygloszono 6 referatów i komunikatów. Jako pierwsza zabrała głos prof. Jadwiga Krzyżaniakowa (Poznań), która przedstawila referat „W kręgu kultury uniwersyteckiej - nauczyciele i uczniowien. Kolejny referent, prof. Eugeniusz Wiśniowski (Lublin), omówił siéc szkół parafialnych na przelomie XV i XVI wieku. W dalszej części obrad odczytano referat, nieobecnego na sali, prof. Jacka Wiesiołowskiego (Poznań), poświęcony szkolnictwu wielkopolskiemu końca średniowiecza. Następnie głos zabrał dr Jan Ryś (Kraków), który scharakteryzował rolę szkół kolegiackich w nauczaniu kościelnym w okresie średniowiecza.

Następnymi referentami byli: mgr Adam Fijalkowski (Warszawa), który zajął się zagadnieniem szkolnictwa parafialnego na Mazowszu w XV-XVI wieku oraz dr Jan Krukowski (Kraków), ten ostatni zaprezentował referat „Nauczyciele krakowskich szkół parafialnych w XVII wieku". Wystąpienie dr H. Patkowej (Praga), poświęcone było zagadnieniu bractw w średniowiecznych Czechach. Prof. Stanisław Bylina (Warszawa) omówił katechezę ludności wiejskiej w późnośredniowiecznej Polsce, a mgr Wlodzimierz Batóg (Kielce) zaprezentował komunikat na temat wędrownego kaznodziejstwa w „Opowieściach kanterberyjskich” Geoffreya Chaucera. Dr Krzysztof Bracha (Kielce) przedstawił referat „Pierwsze przykazanie w katechezie późnośredniowiecznej w świetle Komentarzy do Dekalogu". Pierwszy dzień obrad zakończył komunikat mgr Beaty Wojciechowskiej (Kielce), poświęcony treściom edukacyjnym jasełek w XV i w pierwszej połowie XVI wieku.

Drugi dzień konferencji otworzyło wystąpienie prof. Edwarda Potkowskiego (Warszawa), który przedstawił szkołę średniowieczną jako ośrodek kopiowania tekstów edukacyjnych.

Po nim głos zabrał prof. Ryszard Kiersnowski (Warszawa); jego referat ukazywał wartości dydaktyczne w numizmatyce średniowiecznej. Prof. Alicja Karłowska-Kamzowa (Poznań) omówila ilustracje traktatu Jakuba de Cessolis „Księga figur szachowych” jako narzędzie nauczania od połowy XIV do poczatku XVI wieku. Referat dr Małgorzaty Wilskiej (Warszawa) pokazał edukacje dworską, jej sposoby i instrumenty nauczania na przykładzie dworu jagiellońskiego. Prof. Wojciech Iwańczak (Kielce) zajał się w swoim wystąpieniu problemem wychowania rycerskiego w średniowiecznych Czechach, a mgr Beata Janowska (Warszawa) przedstawiła edukację dziewcząt w Polsce XV wieku. Następnie glos zabrał dr Marian Chachaj (Lublin), który zaprezentował referat „Wykształcenie a kariera w Polsce XVI wieku”. Wystąpienie prof. Henryka Gmiterka 
(Lublin) poświęcone było modelowi wychowania i edukacji kandydatów na duchownych w polskim środowisku Jadnoty Braci Czeskich. Drugi dzień sesji zakończył referat dr Romana Pelczara (Rzeszów) pt. „Bursy muzyków w strukturze szkolnictwa zakonnego na Rusi Czerwonei w XVII - XVIII wieku".

Ostatni dzień konferencji (20.05) rozpoczął komunikat prof. Piotra Radzikowskiego (Kielce) zatytulowany „U źródel współczesnego uniwersytetu. Pierwszy humanista hiszpański król Alfons X i jego ustawodawstwo szkolne". Po nim zabrał głos prof. Lech Mokrzecki (Gdańsk), który mówił o luterańskich gimnazjach akademickich w strukturze oświaty okresu staropolskiego. Konferencję zakończyło wystąpienie dr Adama Witusika (Lublin), poświęcone pierwszym profesorom Akademii Zamojskiej.

Krzysztof Kaczmarek

\section{Nauczyciel - wczoraj - dziś - jutro}

To tytul konferencji naukowej, która odbywała się w dniach od 21 do 23 września 1995 roku w Poznaniu. Zorganizowana została z inicjatywy Zakładu Dydaktyki Historii Instytutu Historii Uniwersytetu im. A. Mickiewicza i Krajowej Komisji Dydaktyki w ramach dyskusji nad modelem edukacji historycznej współczesnego pokolenia. Uczestniczyli w niej przedstawiciele wszystkich środowisk akademickich, Ministerstwa Edukacji Narodowej, Wydawnictw Szkolnych, Kuratorium oraz nauczyciele, studenci, a także goście z Czech i Francji.

Celem spotkania było przybliżenie problemów nauczycieli historii w obliczu zachodzących przeobrażeń w świecie i w kraju. Umoźliwiło ono poddanie ocenie programów kształcenia wypracowanych na poznańskiej uczelni pod kątem kształtowania osobowości intelektualnej i kondycji zawodowej kończących studia, w przeważającej większości nauczycieli historii.

Prestiz konferencji podnosiło odbywające się kolokwium naukowe $z$ udziałem polskich i francuskich uczonych na temat: Wyjaśnianie w historii. Problem historiograficzny i dydaktyczny. Do rangi wykładu inaugurującego wyniesiony został referat prof. dr J. Topolskiego na temat: "Problemy transmisji wiedzy historycznej. Edukacja szkolna". W dalszej kolejności (poszczególne dni) prezentowane były referaty i komunikaty w trzech płaszczyznach czasowych. Prof. dr hab. $L$. Mokrzecki (UG-Gdańsk) przedstawił nam pierwszych nauczycieli historii w szkolnictwie staropolskim. Problemy nauczyciela dnia dzisiejszego w swym referacie omówił prof. dr hab. A. Zielecki (WSP-Rzeszów). Odnotować, w tym miejscu, należy blok wystąpień omawiających model nauczyciela historii. Współczesny wzorzec polski przeanalizowała prof. M. Kujawska (UAM-Poznań). Prof. Henri Maniot (Paryż VII) zapoznał uczestników konferencji z modelem nauczyciela we Francji, prof. dr hab. Otto Zwettler z modelem w Czechach, a prof. dr hab. J. Centkowski (WSP-Rzeszów) zaprezentował wyznaczniki niemieckiego wzorca. Autorem perspektywicznego modelu nauczyciela historii był prof. dr hab. J. Maternicki (UW-Warszawa, WSP-Rzeszów). Wokól referatów i komunikatów ogniskowała się dyskusja, $w$ której poruszono nurtujące środowisko problemy. W trakcie obrad wysłuchano łạcznie trzydziestu referatów i komunikatów oraz kilkanaście dodatkowych, ciekawych wypowiedzi.

Z satysfakcją odnotować należy zainteresowanie uczestników konferencji poznańskim modelom kształcenia przyszłych kadr nauczycielskich. Jego istotę stanowi - swojego rodzaju novum - integracja programów nauczania psychologii, pedagogiki z dydaktyką historii, ściśle powiązaną z podstawami teoretycznymi tej nauki.

Konferencję podsumował prof. dr hab. J. Maternicki formułując wnioski w odniesieniu do: wczoraj: podkreślił, że w trakcie spotkania zaprezentowane zostało nowe spojrzenie na edukację XVI, XVII, XVIII stulecia, dostrzeżony został rozwój refleksji dydaktycznej w czasach przed powolaniem KEN oraz pojawiło się nowe pole badań koncentrujące sį̧ na nauczycielu historii (XIX, XX w.); 